\title{
AZ AlaPtörVÉnY GYAKORLATA ÉS AZ EURÓPAI KONSTITUTCIONALIZMUS*
}

\author{
Szilágyi Emese $e^{1}$
}

A hazai alkotmányosság öre az Alkotmánybíróság. Számos esetben bizonyosodott azonban be, hogy az emberi jogok e testület által garantált védelmi szintje elmarad az európai közös minimumtól. Az EJEB döntései idehaza is egyre több, politikailag érzékeny ügyben hozzák kellemetlen helyzetbe a kormányt és a jogalkotót, amelynek hatására már az Egyezményböl való kilépés gondolata is felmerült. Nem kell azonban a hazai jogalkotónak ilyen drasztikus megoldásokhoz folyamodnia annak elérése érdekében, hogy kibújhasson a strasbourgi testület döntéseinek végrehajtása alól.

\section{Távolodás}

A 2011-es magyar Alaptörvény olyan alkotmányos dokumentum, amelyet már a megalkotása közvetlen pillanatától élénk viták vettek körül. A kritikák egy köre az Alaptörvény tartalmi problémáira fókuszál. Ezek lényegében azt állítják, hogy az Alaptörvény tartalmi hiányosságai távolabb viszik Magyarország új alkotmányos rendszerét a modern alkotmányos hagyományoktól, mint az a '89-es Alkotmány időszakában volt. Az alkotmányok szövegét azonban a jogalkalmazás tölti meg valós tartalommal. Az Alaptörvény kapcsán is felmerült az az érv, hogy a megalkotása során tapasztalható eljárásbeli hiányosságokat majd kiküszöböli a szöveg gyakorlata. Mi több, az alkotmányjogász-közösségben kialakult, az Alaptörvényhez és Magyarország új alkotmányos berendezkedéséhez való viszonyulást a középpontba helyező vitában is meghatározó álláspont, hogy a szöveg esetleges problémái értelmezéssel megoldhatók, de legalábbis a közös európai minimumsztenderdek „,beleolvashatók” a dokumentumba. Ez a nemes, de bonyolult feladat pedig értelemszerüen az Alaptörvény legfőbb értelmezőjére/védelmezőjére, az Alkotmánybíróságra hárul. A tapasztalat azonban azt mutatja, hogy a testületnek nem mindig sikerül megtalálnia az alkotmányos dokumentumban az ehhez szükséges fogódzókat.

Ezért is történhetett meg, hogy 2010 után látványosan megnőtt a más fórumokon, elsősorban a strasbourgi Emberi Jogok Európai Bíróságán (EJEB) jogorvoslatot keresők száma: egyes híradások szerint ${ }^{2} 3$ év alatt mintegy 50\%-kal emelkedett az EJEB-hez intézett beadványok száma. Érdemes azonban azt is megjegyezni, hogy az alapvetően szubszidiárius jellegü nemzetközi emberi jogvédelmi mechanizmus nem alkalmas a belső jogvédelem kiváltására. Mindazonáltal az EJEB döntései számos, szimbolikus ügyben megálljt parancsoltak a közelmúltban a hazai jogalkotási vágtának, s ezek között is megkülönböztetett érdeklődésre tarthatnak számot azok az esetek, amikor azonos tényállásban hazai alkotmánybírósági döntés is született, ám a két bírósági verdikt között ellentmondás figyelhető meg. Ez az ellentét magyarázható akár úgy is, hogy a

\footnotetext{
${ }^{*}$ DOI 10.21867/KjK/2017.2.6.

${ }^{1}$ Szilágyi Emese, tudományos segédmunkatárs, MTA TK JTI

${ }^{2}$ http://hvg.hu/itthon/201424_magyar_ugyek_strasbourgban_iteletido (letöltés dátuma: 2017. július 6.)
} 
strasbourgi testület által képviselt jogvédelmi irány nem áll összhangban a hazai alkotmányos hagyományokkal. Ilyen következtetések elött azonban érdemes áttekinteni a konkrét esetekben az érvelésekben megmutatkozó eltéréseket.

\section{Strasbourg kontra Donáti utca}

Az első ügy, amelyben a strasbourgi és a budapesti testület lényegesen eltérő álláspontra helyezkedett, Baka András panasza, illetve a Legfelsőbb Bíróság (jelenleg Kúria) elnökének és helyetteseinek törvényhozói aktussal való eltávolítása volt. Nem Baka, hanem a Legfelsőbb Bíróság korábbi elnökhelyettese fordult panasszal a hazai Alkotmánybírósághoz idő előtti elmozdításának ügyében. A panaszt a jogállamiság elvét, valamint a diszkrimináció tilalmát és a tisztességes eljáráshoz való jogot kimondó rendelkezésekre alapította az elnökhelyettes. Az Alkotmánybíróság döntésében azonban valójában ezek egyikének a sérelmét sem vizsgálta, így arra sem tért ki, hogy a jogállamiság sérelme megalapozhat-e egyéni jogsérelmet, vagy hogy a tisztességes eljárás követelményeinek megfelelt-e az idő előtti elmozdítás, és a jogorvoslati lehetöség hiánya. A testület mindössze arra fókuszált, hogy az Alaptörvény hatálybalépésének eredményeként bekövetkezett, a legföbb bírói fórumot érintő szervezeti, hatásköri változás az elnökhelyettes megbízatásának határidő előtti megszüntetését kellő mértékben indokolja. Baka András, a LB elnökének ügyében a strasbourgi testület ezzel szemben rámutatott, hogy „a kérelmezőnek a Legfelsőbb Bíróság elnöki mandátumának idő elötti megszüntetését bírói hatáskört gyakorló rendes bíróság vagy más testület nem vizsgálta felül, és nem is volt felülvizsgálható... a Bíróság úgy ítéli meg, hogy az alperes állam hátrányosan befolyásolta a kérelmezö bírósághoz fordulás jogának lényegét." Hovatovább, tekintettel arra, hogy Baka mandátumát nem a Bszi., hanem az Alaptörvény átmeneti rendelkezései szüntették meg, az EJEB még azt is aláhúzta, hogy „olyan jogi szabályozás eredménye volt, amelynek a jogállamiság követelményeivel való összeegyeztethetősége kétséges...” A két testület érvelésében nyilvánvalóan lényeges hangsúlybeli különbségek figyelhetők meg.

Hasonló következtetésekre juthatunk a Szabó és Vissy kontra Magyarország ügyet, illetve az EJEB döntést megelőző hazai határozatot olvasva. A 32/2013. (XI. 22.) AB határozatban a hazai testület a Terrorelhárítási Központ (TEK) hatásköreiröl szóló rendelkezésekkel kapcsolatban a testület ugyan rámutatott arra, hogy az egyének a privátszférájukba történő állami beavatkozást csak annyiban kötelesek elviselni, amennyiben annak alkotmányos törvényi alapja van, azonban ezt a kijelentést követően a vitatott rendelkezések tekintetében nem folytatta le érdemben az alapjogkorlátozási tesztet. A határozatban mindössze annyi történt, hogy a bírák a szóban forgó jogszabályok tartalmának ismertetése után kijelentő módban közölték, hogy azok megfelelnek a „,örvényben meghatározottság és normavilágosság követelményének, mert a szabályozott intézkedés elrendelésének és végrehajtásának körülményeit kielégítő módon tartalmazza." Nem tartották aggályosnak azt sem, hogy a titkos információgyüjtés engedélyezéséről egy politikai aktor, a miniszter hoz döntést. A testület álláspontja szerint a nemzetbiztonsági kockázatok megítélése politikai döntést igényel, ezért a végrehajtó hatalom gyakorlásának körébe tartozik: az „igazságügyért felelős miniszteri engedélyezés szervesen beleilleszkedik az Nbtv. által képviselt osztott engedélyezési rendszer szabályozási koncepciójába, a koncepció pedig 
alkotmányjogilag nem kifogásolható." Végül az Alkotmánybíróság még azt is kijelentette, hogy a miniszter ellenőrzése érdemben megvalósul, hiszen tevékenységét az ombudsman, illetve az országgyülés illetékes bizottsága vizsgálhatja. Teljesen eltérő álláspontot foglalt el az ügyben az Emberi Jogok Európai Bírósága. A strasbourgi testület már érvelése kezdetén abból indult ki, hogy a titkos megfigyelés a demokrácia védelmének álcája alatt alkalmas lehet akár a demokratikus berendezkedés aláásására is. A bírák arra is rámutattak, hogy a jogszabály valójában bárkinek, így akár a lakosság egy nagyobb csoportjának a megfigyelését is lehetővé teszi, ugyanis a hatóságnak az engedélyezési eljárás során nem szükséges igazolnia a megfigyelni szándékozott személy és a potenciális terrorfenyegetettség, nemzetbiztonsági kockázat között fennálló relációt. Másrészt hangsúlyozták, hogy a politikai hatalmi ágnak tekinthető végrehajtó hatalomhoz tartozó miniszteri engedélyezés nem elégséges biztosíték a visszaélés lehetőségével szemben. Végül - szöges ellentétben a hazai alkotmánybírák álláspontjával - felhívták a figyelmet arra is, hogy a minisztert az országgyülés Nemzetbiztonsági Bizottsága irányába terhelö beszámolási kötelezettség, illetve, az ombudsman korlátozott vizsgálati jogosítványai nem tekinthetők elegendő garanciának. Lényegesen eltérő eredményre jutott a hazai alkotmányértelmező testület a kommentekért viselt felelősség kérdésében is az Index és Magyar Tartalomszolgáltatók Egyesülete (MTE) panaszügyében, mint az EJEB. Az alapvető kérdés itt az volt, hogy a tartalomszolgáltató objektív módon felelőssé tehető-e azokért a kommentekért, amelyeknek tartalmáról nem is rendelkezik tudomással. Az Alkotmánybíróság ebben az esetben úgy érvelt, hogy ,„[a] szabályozás alkotmányosan indokolt célt - a személyiségi jogok, egyáltalán a közlésekkel érintettek jogainak védelmét - követi... alkalmas is a cél elérésére..." Ezzel szemben a strasbourgi testület szokatlanul éles hangnemben mutatott rá a hazai bírósági mérlegelés hiányosságaira, különösen arra, hogy ,a magyar bíróságok nem szenteltek figyelmet arra, hogy mi forog kockán a kérelmezők, mint a szabad elektronikus média kulcsfontosságú szereplőinek esetében. Nem bocsátkoztak annak mérlegelésébe, hogy mi módon fogja az internetes véleménynyilvánítási szabadságot befolyásolni az, hogy ha polgári jogi felelősséget alkalmaznak egy hírportál üzemeltetője esetében. A magyar bíróságok az ügy elbírálása folyamatában egyáltalán nem mérlegelték ez utóbbi érdeket a felperes érdeke mellett. Ez a tény önmagában is megkérdőjelezi a kérelmezők véleménynyilvánítási szabadsága nemzeti szintü védelmének megfelelőségét..." Végül a két versengő jog, a véleményszabadság és a jó hírnév védelme közötti mérlegelés elmaradása okán a testület megállapította az Egyezmény 10. cikkének sérelmét.

Láthatjuk tehát, hogy a hazai alkotmányértelmezési gyakorlat - valójában azért, mert a döntések során elmarad az alapjogkorlátozási teszt megfelelő és következetes alkalmazása, a szemben álló érdekek valós mérlegelése - egyre kevésbé alkalmas arra, hogy a közös európai minimumsztenderdek érvényesülését garantálja. Természetesen más szempontok, így az indítványozási lehetőség szükülése és a parlament „felülalkotmányozási” gyakorlata is hozzájárul ahhoz, hogy nem látszik megvalósulni az az optimista forgatókönyv, amely szerint a kifogásolható alkotmányos dokumentum hiányosságait majd annak gyakorlata küszöböli ki. 


\section{Kié a végső szó?}

Az Alkotmánybíróság és a strasbourgi testület széttartó gyakorlata azonban egy meglehetősen borús jövőkép irányába is mutathat. Az EJEB legutóbbi hazánkat érintő döntése kapcsán a legnagyobb kormánypárt úgy foglalt állást, hogy „,a kormánynak meg kell támadnia a strasbourgi ítéletet, ellen kell állnia ennek a nemzetközi nyomásnak." Még az is elhangzott, hogy szükséges lehet Magyarország kilépése az Emberi Jogok Európai Egyezményének fennhatósága alól. ${ }^{3}$ Bár ez a lépés meglehetősen drasztikusnak tünik, léteznek puhább megoldások is annak elérésére, hogy az EJEB döntései ne érvényesüljenek hazánkban. Putyin Oroszországa sem mondta fel az Emberi Jogok Európai Egyezményét, de megtalálta a módot arra, hogy a strasbourgi testület politikailag kellemetlen döntéseit ne kelljen végrehajtania. Ennek a példának az ad alapot, hogy nem ez volna az első eset, amikor az oroszországi jogfejlődés mintaként szolgál idehaza. ${ }^{4}$

Oroszországban 2015 decemberében fogadott el a törvényhozás olyan szabályozást, ${ }^{5}$ amely nyíltan deklarálja az alkotmány felsőbbrendüségét Oroszország vállalt nemzetközi kötelezettségeivel szemben, és felruházza az Alkotmánybíróságot egy olyan hatáskörrel, amelynek értelmében a kormány vagy az elnök indítványára a testület vizsgálhatja a strasbourgi EJEB döntéseinek kompatibilitását az orosz alkotmánnyal, illetve kimondhatja azok alkalmazhatatlanságát. Ezeket a hatásköröket valójában még a jogszabályok parlament általi módosítását megelőzően, egy 2015 júliusában hozott döntésében az orosz Alkotmánybíróság vindikálta magának. 2016 márciusában a Velencei Bizottság egy előzetes véleményt publikált a szabályozásokról, amelyben úgy foglalt állást, hogy mindaddig, amíg az Alkotmánybíróságnak hatásköre van a nemzetközi szerződésbe ütközés vizsgálatára is, egy ilyen jogi szabályozás elméletben nem sérti az állam vállalt nemzetközi kötelezettségeit. Az orosz Alkotmánybíróság 2016. április 12-én a fogvatartottak szavazati jogát érintő korlátozások ügyében született Anchugov és Gladkov kontra Oroszország döntés végrehajthatóságának tárgyában született döntésben élt elöször új jogosítványaival. A bírák kimondták, hogy az EJEB döntésének bizonyos rendelkezései nem végrehajthatók.

Oroszországban a hírhedt Jukosz-ügy jelentette a vízválasztót. A választott megoldás kevésbé drasztikusnak tünik, mint az Egyezményből való kilépés, de az eredmény közel azonos, vagyis az emberi jogok védelmi szintjének jelentős csökkenése. Csak bízni lehet abban, hogy a bangladesi menekültek épp terítéken lévö ügye nem fog Magyarországon hasonló lavinát elindítani.

\footnotetext{
3 http://magyarnarancs.hu/belpol/a-kormanyparok-halal-komolyan-beszelnek-arrol-hogy-kilepunk-azemberi-jogok-europai-egyezmenyebol-103138 (letöltés dátuma: 2017. július 6.)

${ }^{4}$ http://jog.tk.mta.hu/blog/2017/04/civil-torveny-modositasa (letöltés dátuma: 2017. július 6.)

5 http://www.iconnectblog.com/2016/05/russias-constitutional-court-declares-judgment-of-theeuropean-court-impossible-to-enforce/ (letöltés dátuma: 2017. július 6.)
} 